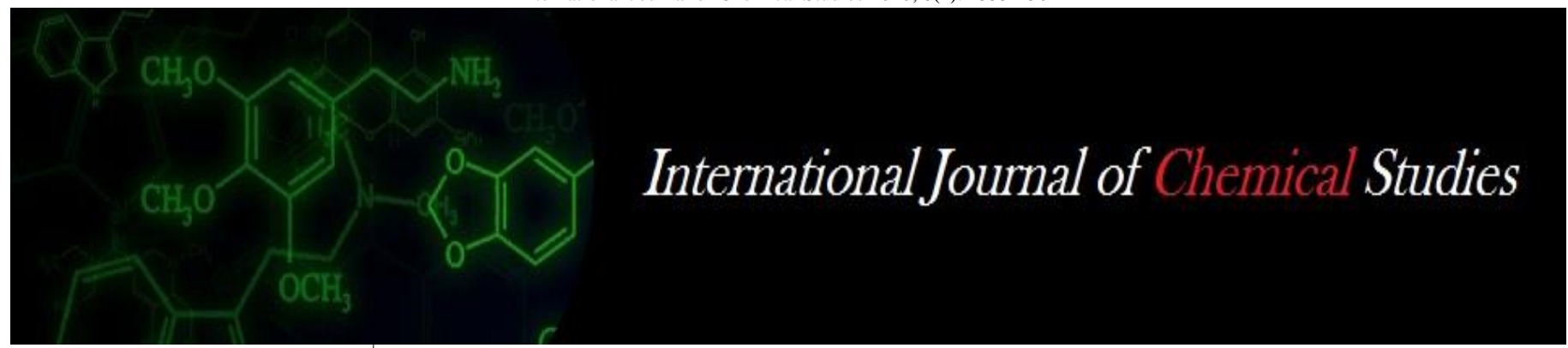

P-ISSN: 2349-8528

E-ISSN: 2321-4902

www.chemijournal.com

IJCS 2020; 8(4): 1555-1561

(C) 2020 IJCS

Received: 08-05-2020

Accepted: 12-06-2020

Neetu

Banda University of Agriculture and Technology, Banda, Uttar

Pradesh, India

\section{Shalini Purwar}

Banda University of Agriculture and Technology, Banda, Uttar

Pradesh, India

\section{Vinita Bisht}

Banda University of Agriculture and Technology, Banda, Uttar

Pradesh, India

\section{Neeraj}

Jharkhand Rai University,

Ranchi, Jharkhand,

Uttarakhand, India

\section{Brijesh KR Maurya}

Banda University of Agriculture and Technology, Banda, Uttar Pradesh, India
Corresponding Author:

Neetu

Banda University of Agriculture and Technology, Banda, Uttar Pradesh, India

\section{Nutritional and therapeutic values of Coccinea grandis: A review}

\author{
Neetu, Shalini Purwar, Vinita Bisht, Neeraj and Brijesh KR Maurya
}

DOI: https://doi.org/10.22271/chemi.2020.v8.i40.9832

\begin{abstract}
Coccinia grandis also known as Ivy Gourd is a nutrient rich fast growing perennial vine plant of Cucurbitaceae family. It is a dioecious, perennial and herbaceous climber or trailing vine with glabrous stems and tuberous roots. Traditionally it is known for its medicinal and nutritional qualities and its all plant parts like roots, leaves and fruits are used in local medicinal purposes like jaundice, diabetes, wound healing, ulcers, stomach ache, skin disease, fever, asthma, cough. It is a wonderful vegetable plant species having various pharmacological properties like analgesic, antipyretic, anti-inflammatory, antimicrobial, antiulcer, antidiabetic, antioxidant, hypoglycemic, hepatoprotective, antimalarial, antidyslipidemic, anticancer, antitussive, mutagenic.
\end{abstract}

Keywords: Analgesic, antioxidant, Coccinia grandis, cucurbitaceae, dioecious

\section{Introduction}

Coccinia grandis (Ivy gourd) is a member of Cucurbitaceae family. It is believed to origin of India (Nath, 1966) ${ }^{[46]}$. Ivy gourd is a perennial vine crop, grown in tropical and Sub-tropical region. Ivy gourd is grown for their immature tender fruits, test like a cucumber and are used as salad and preparation of various vegetable. In southern Asia, Ivy gourd is cultivated for its long slender edible young shoot and fruit (Linney, 1986) ${ }^{[34]}$. Ivy gourd has a many medicinal values. It is rich in vitamin $\mathrm{C}$, which is straightening the bones. It also provided vitamin B1 and B2 and also small amount of vitamin A and tendril of Ivy gourd is also rich in mineral like potassium, calcium and iron. All part of plant are used for treating various disease, leaves extraction of Coccinia grandis for antibacterial activities (Bhattacharya 2010) ${ }^{[10,11]}$, root are used for antidiabetic, skin diseases, removes pain in joint, urinary tract infection (Pekamwar et al, 2013) ${ }^{[48,49]}$ and to help in controlling diabetes (Shibib et al. 1993, Deokate and Khadabadi 2011) ${ }^{[57,17]}$. In India, the family Cucurbitaceae is represented by 36 genera and 100 species (Chakravarty, 1982) ${ }^{[15]}$. Cucurbitaceae are a major family among economically important domesticated species, particularly those with edible fruits including cucumber (Cucumis sativus), melon (Cucumis melo), watermelon (Citrullus lanatus), squash and pumpkin (Cucurbita spp.), bitter melon (Momordica charantia), chayote (Sechium edule), loofah (Luffa spp.), bottle gourd (Lagenaria siceraria), snake gourd (Trichosanthes cucumerina var. anguina) and wax gourd (Benincasa hispida). Some of these represent the earliest cultivated plants and known for their medicinal properties and so many other uses. Since ancient times, particularly Lagenaria spp., those have hard- shelled fruits, which have been used to manufacture musical instruments and so many containers. It is indigenous species to Bengal and other parts of India. $C$. indica grows abundantly all over India, Tropical Africa, Australia, Fiji and throughout the oriental countries. The plant has also been used extensively in Ayurvedic and Unani practice in the Indian subcontinent (Wealth of India, 1992) ${ }^{[70]}$. It has long tuberous fleshy roots, smooth and green fruits. Microscopy of root shows parenchyma, phelloderm, pericyclic fibers, stone cells, starch grains.

Some other Cucurbits are also used in the indigenous system of medicines they are: Lagenaria siceraria, Trichosanthes dioica, T. cucumerina, T. cucumerina var. anguina, and Benincasa hispida are rich in protein and vitamin C. Each and every part of pointed gourd has high nutritional value. The roots contain amorphous Saponin. Species of Momordica spp. are used in diabetes. Citrullus lanatus seeds are used as cooling medicine. Coccinia grandis roots, stems, and leaves has been used to curing the skin diseases. 
Fruits of melons are eaten when ripe and are also used in chronic eczema. Bottle gourd (Lagenaria siceraria), ribbed gourd (Luffa acutangula), white gourd (Benincasa hispida), cucumber (Cucumis sativus), and pointed gourd (Trichosanthes dioica) are some of the most common

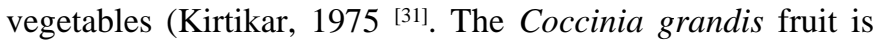
used as vegetable when green and eaten fresh when ripened into bright scarlet colour (Sastri, 1950) ${ }^{[50]}$. Every part of this plant is valuable and used in various diseases; bronchial catarrh, bronchitis and Unani systems of medicine for ring worm, psoriasis, small pox, scabies (Perry, 1980) ${ }^{[50]}$ and other itchy skin eruptions and ulcers (Behl et al., 1993) ${ }^{[8]}$. Oil of this plant is used as an injection into chronic sinuses. The plant is used in decoction for gonnorhoeae (Nadkarni, 1976) [43], diabetes and also useful in dropsical condition, pyelitis, cystitis, strangury, snake bite, urinary gravel and calculi (Jayaweera, 1980; Nadkarni, 1976) ${ }^{[29,43]}$. It is also useful to induce perspiration in fever and cures sores in the tongue (Anon., 1992) ${ }^{[5]}$. It has antilithic (Jayaweera, 1980) [29], hypolipidimic (Presanna Kumar, et al., 1997) [51], antimutagenic (Kusamran et al., 1998) ${ }^{[33]}$ and hypoglycemic activities (Chopra \& Bose, 1925; Gupta, 1963; Brahmachari et al. 1963; Kumar et al. 1997; Nahar et al. 1998) ${ }^{[16,27,13,51,44]}$. Vegetables are considered to be protective foods and highly beneficial for the maintenance of good health and prevention of diseases. Medical nutrition and pharmaceutical applications of plant origin will be the new research mandate for healthy future. Ivy gourd fruits are rich in lycopene $(5.68 \mathrm{mg} / 100 \mathrm{~g})$, $\beta$-carotene $(2.24 \mathrm{mg} / 100 \mathrm{~g})$ and leaves contain protein (3.3$4.9 \mathrm{~g})$, vitamin A (8000-18000 IU). Fruits are antidiabetic and having antioxidant property. In Ayurveda, it is used for skin eruption, tongue sores and earache. They are sources for nutrients such as carbohydrates, proteins, vitamins, fibre and minerals required for human health. According to some generous estimates, almost $80 \%$ of the present day medicines are directly or indirectly obtained from plants.

\section{Nutritional Value of Coccinea grandis}

Khatun et al., 2012 evaluated the different nutrient Components of Coccinia grandis are carbohydrate-12.62\%, total protein- $15 \%$, water soluble protein-11.25\%, lipid- $4.0 \%$, total phenol- $61.92 \mathrm{mg} / 100 \mathrm{~g}$, vitamin C-25.55 $\mathrm{mg} / 100 \mathrm{~g}, \beta-$ carotene-70.05mg/100g, potassium-3.3 $\mathrm{mg} / 100 \mathrm{~g}$, phosphorous- $1.15 \mathrm{mg} / 100 \mathrm{~g}$, sodium $-0.95 \mathrm{mg} / 100 \mathrm{~g}$, iron- 2.23 $\mathrm{mg} / 100 \mathrm{~g}$ and calcium-3.79 mg/100 g. Fruits of Coccinia grandis contains steroids, saponin, ellagic acid, terpenoids, lignin, other compound like alkaloids, tannins, flavonoids, glycosides, phenols, B-amyrin acetate, lupeol, taraxerol, $\beta$, Bcarotene, lycopene, cryptoxanthin, xyloglucen, carotenoids and $\beta$-sitosterol.

Table 1: Nutritional value per $100 \mathrm{~g}$ of edible portion (fruit) of Coccinia Grandis

\begin{tabular}{|c|c|}
\hline Components & Amount \\
\hline Energy & $21 \mathrm{~K} . \mathrm{Cal}$ \\
\hline Protein & $1.4 \mathrm{~g}$ \\
\hline Carbohydrate & $3.4 \mathrm{~g}$ \\
\hline Fat & $0.2 \mathrm{~g}$ \\
\hline Calcium & $25 \mathrm{mg}$ \\
\hline Iron & $0.9 \mathrm{mg}$ \\
\hline
\end{tabular}

Table 2: Phytochemical properties of different parts of Coccinea Chemical constituent of different plant parts of Coccinea (Deokate et al., 2011).

\begin{tabular}{|c|c|}
\hline Plant parts & Constituents \\
\hline Roots & $\begin{array}{l}\text { Triterpenoid,saponin, coccinioside }-\mathrm{k}(\mathrm{i}) . \mathrm{C}_{41} \mathrm{H}_{66} \mathrm{O}_{12} \\
\text { Flavonoid glycoside ombuin 3-o- arabinofuranoside } 3 \text { - o- } \beta \text { - }(\alpha-1 \text { - arabinopyranosyl)- }(1 \rightarrow 2)-\beta \text {-d-glucopyranosyl- }(1 \rightarrow 3)-\beta \text { - } \\
\text { hydroxylup - 20(29)- en-28- oic acid. Lupeol, } \beta \text {-amyrin, and } \beta \text { - sitosterol. Stigmast - } 7 \text { - en-3-one, }\end{array}$ \\
\hline Fruits & $\begin{array}{c}\text { Taraxerone, taraxerol, and (24R)-24- ethylcholest- 5- en- 3ß- ol glucoside. B- carotene, lycopene, cryptoxanthin, and apo- 6'- } \\
\text { lycopenal B- sitosterol and taraxerol }\end{array}$ \\
\hline Aerial parts & Heptacosane Cephalandrol, C29H58O tritriacontane C33H68 B- sitosterol alkaloids Cephalandrine a and Cephalandrine b. \\
\hline
\end{tabular}

\section{Botanical description}

Coccinia grandis is a fast-growing perennial vine crop that grows several meters long. It can form dense mats on lands that easily cover shrubs and small trees.

\section{Leaves}

Their leaves are arranged alternately along the stems; the shape of the leaves varies from heart to pentagon shaped. (Up to $10 \mathrm{~cm}$ wide and long). The upper surface of the leaf is hairless, whereas the lower is hairy and simple tendrils. There are 3-8 glands on the blade near the leaf stalk.

\section{Flower}

Flowers are star-shape, large and white in colour. The calyx has five subulate, recurved lobes, each 2-5 $\mathrm{mm}$ long on the hypanthium; peduncle $1-5 \mathrm{~cm}$ long. The corolla is white, campanulate, $3-4.5 \mathrm{~cm}$ long, deeply divided into five ovate lobes. Each flower has three stamens. The Coccinia grandis flower ovary is inferior. Staminate is solitary, rarely in axillary clusters of 2-3, pedicels $15-50 \mathrm{~mm}$ long, lobes of calyx is subulate, recurved, $2-5 \mathrm{~mm}$ long, corolla lobes ovate, white, long about 15-20 $\mathrm{mm}$; pistillate flowers solitary on stalks10-30 mm long, hypanthium 10- $15 \mathrm{~mm}$ long (Starr et al., 2003) ${ }^{[62] .}$

\section{Fruit}

The fruit of Coccinia grandis is red colour, shape ovoid to elliptical, 25-60 mm long, 15-35 $\mathrm{mm}$ in diameter, glabrous, hairless on stalks. Seeds 6-7 mm long, tan-colored and thick margins.

\section{Root}

The roots and stems are succulent in nature, tuberous and most likely facilitate the plant to survive prolonged drought. Dispersal of Coccinia grandis are done by the humans and also spread by birds and other animals, pigs, moved unintentionally on equipment or on wood and germinate where they land. Hybridization and clonal selection are one of the viable methods to develop improved clone in ivy gourd (Maurice et al., 2012; Ajmal Ali et al., 2005-2006) ${ }^{[38,3]}$. 
Table 3: Medicinal value of various parts of Coccinea grandis (Pekamwar et al., May, 2013) ${ }^{[48,49]}$.

\begin{tabular}{|c|c|}
\hline Leaf & $\begin{array}{c}\text { Antidiabetic, oxidant, larvicidal, GI disturbances, Cooling effect to the eye, Gonorrhea, hypolipidemic, skin diseases, urinary tract } \\
\text { infection. }\end{array}$ \\
\hline Fruit & Hypoglycemic, analgesic, antipyretic, Hepatoprotective, tuberculosis, eczema. anti-inflammatory \\
\hline Stem & Expectorant, antispasmodic, asthma, bronchitis, GIT disturbances, urinary tract infection, skin diseases, \\
\hline Root & Hypoglycemic, antidiabetic, skin diseases, removes pain in joint, urinary tract infection \\
\hline
\end{tabular}

\section{Pharmacological Activities Antibacterial}

Bhattacharya et al., (2010) ${ }^{[10,11]}$ analyzed the aqueous extract of leaves of Coccinia grandis for antibacterial activity against Shigella flexneri NICED, Bacillus subtilis, Escherichia coli, Salmonella choleraesuis, Shigella dysenteries, and Shigella flexneri. Aqueous extract of Coccinia grandis showed more significant antibacterial activity in comparison to ethanol extract. A polar moiety of the extract is more responsible for antibacterial properties. The chloroform extracts of Coccinia cordifolia moderately active against Sarcina lutea, Bacillus subtilis. Ethyl acetate extracts active against staphylococcus aurous. Hexane extract active against the Sarcina lutea, Pseudomonas aeruginosa (Bulbul et al., 2011) ${ }^{[14]}$.

Sivaraj et al. (2011) ${ }^{[60]}$ has been evaluated the antibacterial activity of Coccinia grandis leaf extract with solvents like acetone, ethanol, methanol, aqueous and hexane against five bacterial species. Ethanol leaf extract of Coccinia grandis showed high antibacterial activity against $S$. pigeons, E. Coli, B. Ceres, K. pneumonia and S. aureus (Sivaraj et al., 2011) [60]. Antibacterial activity of Coccinia grandis extract tested against the six gram positive and gram negative bacteria, Hexane extract moderately active against all gram positive and gram negative bacteria except Proteus mirabilis. Ethyl acetate extracts moderately antibacterial against all except Proteus mirabilis and staphylococcus aeruginosa (Farukhh et al., 2008; Tamilselvan et al., 2011) [24, 67].

\section{Anthelmintic}

Methanolic extract of Coccinia grandis posses the anthelmintic activity. Methanolic extract of Coccinia grandis acts through paralyzing the worm. (Tamilselvan et al. 2011) [67].

\section{Antioxidant}

Moideen (2011) [39] evaluated Ethanol extract of root of Coccinia grandis contain flavonoids, Methanol extracts of the fruit of Coccinia grandis posses the potent antioxidant activity. The methanol extract of Coccinia grandis contains glycoside and flavonoid. The antioxidant activity of Coccinia grandis is due to the reducing power ability, hydrogen peroxide scavenging potential (Deshpande et al., 2011) [1] Ethanol and methanol extract shows the antioxidant activity (Ashwini et al., 2012) [6] Coccinia grandis stem extract containing solvent petroleum, chloroform and ethyl acetate shows antioxidant activity. Ethyl acetate possess potent antioxidant activity than petroleum (Deshpande et al., 2011) ${ }^{[1]}$ Coccinia grandis methanol extract and leaf powder contain the antioxidant principle (Mujumder et al., 2008) ${ }^{[41]}$.

\section{Antiulcer}

Aqueous extract of Coccinia grandis at doses of 250 and 500 $\mathrm{mg} / \mathrm{kg}$ produced significant inhibition of the gastric lesions induced by pylorus ligation induced ulcer and ethanol induced gastric ulcer. The extract showed significant reduction in ulcer index, free acidity and gastric (Girish et al., 2011) ${ }^{[25]}$ On the other hand; Manoharan (2010) ${ }^{[37]}$ studied the Ethanol, aqueous and total aqueous extract for antiulcer activity in pylorus ligation induced gastric ulcer.

\section{Antimalarial}

Extract of Coccinia grandis shows excellent antiplasmodial activity against the Plasmodium falciparum (Sundaram et al., 2012) ${ }^{[63]}$. Aqueous leaf extract of Coccinia grandis decreases the SGPT, SGOT, ALP, total protein, blood urea nitrogen concentration. Hydrophilic moiety of Coccinia grandis extract is responsible for antimalarial activity. The extract significantly reduces the Plasmodium berghei parasite strength in mice (Samanta et al., 2011) ${ }^{[54]}$. The methanolic extract from Coccinia grandis which is used for reducing the larvicidal activity (Rahumann., 2008) ${ }^{[52]}$.

\section{Antiinfammatory}

Deshpande (2011) [1] evaluated the aqueous extracts of Coccinia grandis leaves and stem for the anti-inflammatory activity against formaldehyde induced paw edema in rats. The formaldehyde causes the cell damage and which provokes the production of histamine, prostagrandis bradykikin and serotonin. Aqueous extract of leaves showed more significant percentage inhibition of paw edema than the aqueous extract of the stem and standard, used as indomethacin. Formaldehyde induced inflammation results production of endogenous mediators, such as; histamine, serotonin, prostaglandins, and bradykinin treated with Coccinia grandis extract (Bernard et al., 1998) ${ }^{[9]}$.

\section{Antipyretic}

Aggarwal (2011) [1] was evaluate methanolic extract of Coccinia grandis for antipyretic activity at the doses of 100 and $200 \mathrm{mg} / \mathrm{kg}$ in yeast-induced fever. The extract showed antipyretic activity by influencing the prostaglandin biosynthesis. Prostaglandin is considered as a regulator of body temperature.

\section{Analgesic}

Analgesic action of the active compound(s) in the methanol extract of Coccinia grandis May be mediated through peripheral but not central mechanism. Coccinia grandis reduce the complications produced by acetic acid (Aggarwal et al., 2011) ${ }^{[1]}$.

\section{Hypoglycemic}

Mallick (2007) [35] studied the combined extracts of Musa paradisiaca and Coccinia indica aqueous extract of leaf for antidiabetic activity in streptozotocin induced diabetes rats. The ethanolic extract of the aerial part decreases blood glucose levels and lipid parameters in streptozotocin induced diabetic rats at 100 or $200 \mathrm{mg} / \mathrm{kg}$. Chronic administration of fruit extract $200 \mathrm{mg} / \mathrm{kg}$ for 14 days reduces the blood glucose level in alloxan induced. diabetic rat (Gunjan et al., 2010) ${ }^{[26]}$. The aqueous extract of Coccinia indica reduced the blood glucose level; also reduced the cholesterol, protein and urea with prolonged treatment. Coccinia grandis stimulated gluconeogenesis, or inhibited glycogenolysis in the diabetic 
rat liver. Treatment with Coccinia extract increases the total protein, SGPT, SGOT (Doss et al., 2008) ${ }^{[20] .}$

The Coccinia indica leaves extract exerts hypoglycemic activity on blood glucose and cholesterol, TG, LDL, VLDL level in alloxan induced diabetic rats (Manjula et al., 2007) [36]. The hypoglycemic activity of Coccinia grandis fruit evaluated by using alloxan induced diabetic rat. Ethanolic extract shows the decreased blood glucose level.

Pectin from fruit reduces the blood glucose by decreasing the absorption of glucose from the intestine and increasing liver glycogen and decreasing glycogen phosporylase. Combined Methanolic extract of leaves of Coccinia indica and Salvadora oleoides shows the hypoglycemic activity (SaklaniI et al., 2012). Alcoholic extract of Coccinia grandis leaves (Eliza Jose, 2010) ${ }^{[23]}$ and stem have the capacity to lower the blood glucose level in normal fasted rats (Doss et al., 2008) [20] Ethyl acetate extract and petroleum ether extract of Coccinia contains triterpines, alkaloid, flavonoid, $\beta$-carotene which is responsible for the hypoglycemic activity.

\section{Antifungal}

Bhattacharya $(2010)^{[10,11]}$ found the antifungal activity of the Coccinia grandis leaves extract against the Candida albicansII, Candida tropicalis, Aspergillus Niger, Saccharomyces cerevisiae, Candida tropicalis II, Cryptococcus neoformans and Candida albicans ATCC. Aqueous extract is more sensitive for both strains of Candida albicans and Ethanolic extract is more sensitive for Aspergillus Niger and both strains of Candida albicans (Bhattacharya et al., 2010) ${ }^{[10,11]}$.

\section{Hepatoprotective}

Vadivu (2008) revealed the alcoholic extract of the fruit of Coccinia grandis for Hepatoprotective activity against CCl4induced Hepatotoxicity in experimental rats, Treatment with $250 \mathrm{mg} / \mathrm{kg}$ ethanolic extract of fruit significantly reduced the SGPT, SGOT and bilirubin level. Hepatoprotective activity of the extract may be due to the antioxidant effects of flavonoid found to be present in the fruits. Flavonoids, triterpens and tannin were antioxidant agent present in Coccinia grandis and may interfere with free radical formation confirmed that Hepatoprotective activities of certain flavonoids are known. (Vinothkumar et al., 2009; Anil Kumar. 2012; DR. Krishnkumari et al. 2011; Sunilson., et al. 2009) [29, 4, 21].

\section{Antidyslipidemic}

Singha (2007) ${ }^{[58]}$ evaluated chloroform extract of Coccinia grandis leaves for antidyslipidemic activity by lowering the triglycerides and cholesterol level in hamsters. Chloroform extract of Coccinia grandis leaves containing polyprenol, lowers the plasma lipid profile then increasing high density lipid cholesterol and total cholesterol ratio. C60-polyprenol isolated first time from this plant. It drastically decreased serum triglycerides by $42 \%$, total cholesterol $25 \%$ and glycerol $12 \%$, in high fat diet feed dyslipidemic hamsters at the dose of $50 \mathrm{mg} / \mathrm{kg}$ body weight. Aqueous and ethanolic extracts of leaves can be used for control of obesity (Mishra et al., 2012) ${ }^{[59]}$.

\footnotetext{
Anticancer

There have so many vegetables occurred to reduce the risk of cancer. The anticancer activity of the Coccinia grandis is due to it antioxidant nature. The antioxidant nature of Coccinia grandis reduces the ferrocynaide to ferrous and Hydrogen peroxide scavenged from Coccinia grandis neutralizes to water (Behera et al., 2012) ${ }^{[7]}$.
}

Bhattacharya (2011) ${ }^{[54]}$ found the aqueous extract of leaves of Coccinia grandis for anticancer activity. Nitric oxide is a free radical which acting an important role in the pathogenesis of pain, inflammation. The antioxidant principle of Coccinia grandis decreases the nitrite generated by decomposition. Graded response produced by the cell is comparatively less. Coccinia grandis significantly reduced viable cell count and increased nonviable cell count suggesting comparable anticancer property with that of the reference drug (Vinblastine) (Nanasombat et al., 2009; Bhattacharya et al., 2011) ${ }^{[45,54]}$

\section{Antitussive}

Pattanayak (2009) ${ }^{[47]}$ analyzed the methanol extracts of the fruit of Coccinia grandis for analgesic activity and extensively used to get relief from asthma and cough by the indigenous people of India. The methanol extracts of the fruit of Coccinia grandis show the presence of alkaloid, tannin, steroid, triterpenoid, glycoside, carbohydrates and reducing sugar. The Antitussive activity of methanol extract has been compared with that of codeine (Antitussive drug). The methanol extract of Coccinia grandis fruit showed the significant decrease in cough induced by the chemical simulation similar to codeine phosphate in a dose dependant manner. The methanol extract produces maximum inhibition of cough at $90 \mathrm{~min}$. The highest inhibition of cough $(56.71 \%)$ was produced by the extract of the $400 \mathrm{mg} / \mathrm{kg}$ dose level at 90 min. The methanol extract act through the central nervous system.

\section{Mutagenic effect}

Aqueous extract of leaves of Coccinia grandis showed inhibition of growth and mutagenesis on Neurospora crassa by a gradual decrease of growth of mycelia. This result indicates that Coccinia grandis plant shows mutagenic effect on Neurospora crassa. (Bhuiyan et al., 2009) ${ }^{[12]}$.

\section{Alpha-amylase inhibition}

Jaiboon (2011) ${ }^{[28]}$ evaluated the methanolic extract of Coccinia grandis for alpha amylase inhibitory activity. The dried plant material extracted with $50 \%$ aqueous methanol (10 $\mathrm{ml} / \mathrm{g}$ drywt.) and redissolved in 50\% aqueous DMSO $(10 \mathrm{ml} / \mathrm{g}$ dry wt.) and subjected to alpha-amylase inhibitory activity. The Coccinia grandis showed the $81.13 \%$ of alpha amylase inhibitory activity.

\section{Conclusion}

Coccinia grandis is an important source of many pharmacological and medicinally important chemicals. In this review study Coccinia grandis medicinal plants play a fundamental role against various diseases. Coccinia cordifolia is a true miracle of nature because of the presence of effective chemical constituents responsible for diversified pharmacological applications. Also, it has been developed by some medicinal industries as a drug. The various parts of plant extracts have significant analgesic, antipyretic, antiinflammatory, antimicrobial, Antiulcer, antidiabetic, antioxidant, anticancer, antitussive hypoglycemic, hepatoprotective, antimalarial, antidyslipidemic.

\section{Reference}

1. Aggarwal U, Suralkar S, Chaudhari SV, Deshpande A, Garud S Talele. Analgesic and antipyretic activity of methanolic extract of Coccinia grandis L. Leaves in experimental animals. Research Journal of 
Pharmaceutical, Biological and Chemical Sciences. 2011; 2:175-182.

2. Kumar A. A review of hepatoprotective herbal drugs. international journal of research in pharmacy and chemistry. 2012; 2:92-102.

3. Ajmal Ali M, Pandey Arun K. Systematic Studies on the Family Cucurbitaceae of Eastern Bihar, India. Cucurbit Genetics Cooperative Report. 2005-2006; 28-29-66-69.

4. Anil Kumar. A review of hepatoprotective herbal drugs. international journal of research in pharmacy and chemistry. 2012; 2:92-102.

5. Anonymous. Dictionary of Indian Medicinal Plants, Central Institute of Medicinal and Aromatic Plants, India, 1992.

6. Ashwini M, Lather Nisha, Shivaji Bole, Vedamurthy AB, Sam Balu. In vitro antioxidant and antiinflammatory activity of Coccinia grandis. International Journal of Pharmacy and Pharmaceutical Sciences. 2012; 4:239242.

7. Behera SK, Dash V. Some Indian vegetable used as an anticancer agent. International journal of advanced pharmaceutical and biological sciences. 2012; 2:250-264.

8. Behl PN, Arora RB, Srivastava G, Malhotia. Herbs useful in Dermatological therapy, CBS Publishers and Distributor, Delhi, 1993.

9. Bernard Bensita Mary, Pakianathan Nilani, Madhu C Diwakar. On the antipyretic, antiinflammatory, analgesic and molluscicidal properties of Polyscias fruticosa (L) harms. Ancient Science of Life. 1998; 17(4):313-319.

10. Bhattacharya Bolay et al., In vitro evaluation of antifungal and Antibacterial activities of the plant Coccinia grandis (L.) Voigt. (Family-Cucurbitaceae). Journal of Phytology. 2010; 2(11):52-57.

11. Bhattacharya Bolay. In vitro evaluation of antifungal and Antibacterial activities of the plant Coccinia grandis (L.) Voigt. (Family- Cucurbitaceae). Journal of Phytology. 2010; 2(11):52-57.

12. Bhuiyan MN et al. Mutagenic effect of Coccinia cordifolia leaf extract on $\mathrm{n}$. crassa fungus. Bangladesh Journal of science and research. 2009; 44:215-220.

13. Brahmachari HD, Augusti KT, Birla C, Pilani. Orally effective hypoglycemic principles from Coccinia indica., Journal of Pharmacy and Pharmacology. 1963; 15(6):411-412.

14. Bulbul Israt Jahan, Nathan Laizuman, Haque Mahmuda. Antibacterial Cytotoxic and antioxidant activity of chloroform, n-hexane and ethyl acetate extract of plant Coccinia cordifolia. Agriculture and Biology journal of north America. 2011; 2(4):713-719.

15. Chakravarty HL. Fascicle Flora of India. Fascicle II Cucurbitaceae. B. S. I. Calcutta, 1982.

16. Chopra RN, Bose JP. Cephalandra indica (Telakucha) in diabetes. Indian J Med. Res. 1925; 13:11-16.

17. Deokate UA, Khadabadi SS. Pharmacology and phytochemistry of Coccinia indica. Journal of pharmacognosy and phytotherapy. 2011; 3(11):155-159.

18. Deshpande SV et al. In vitro antioxidant study of petroleum ether chloroform and ethyl acetate fractions of Coccinia grandis stems extract. International journal of chemical sciences. 2011; 9(1):80-86.

19. Deshpande SV, Patil MJ, Parmar KK, Daswadkar SC, Khodade RB. A study of antioxidant activity of fruit extract of Coccinia grandis L voight. International Journal of Drug Research and Technology. 2011; 1(1):69-72.
20. Doss A, Dhanabalan R. Anti-hyperglycemic and Insulin Release Effects of Coccinia grandis (L.) Voigt Leaves in Normal and Alloxan Diabetic Rats. Ethno botanical Leaflets. 2008; 12:1172-75.

21. Dr. Krishnkumari S, Bhuvaneshwari P, Rajeswari P. The ameliorative potential of Coccinia grandis of serum and liver marker enzymes and lipid profile in streptozotocin induced diabetic rat. Ancient science of life. 2011; 31:2630.

22. Dr. Krishnkumari S, Bhuvaneshwari P, Rajeswari P. The ameliorative potential of Coccinia grandis of serum and liver marker enzymes and lipid profile in streptozotocin induced diabetic rat. Ancient science of life. 2011; 31:2630.

23. Eliza Jose, Usha PTA. Evaluation of antidiabetic efficacy of Coccinia indica in rats. Indian Journal of animal Research. 2010; 144(3):68-172.

24. Farukhh Umbreen., Shareef Huma., Mahmud Shaukat., Ali Syed Ayub and Ghazala H. Rizwani. Antibacterial activities of Coccinia grandis L., Pakistan Journal of Botany. 2008; 40(3):1259-1262.

25. Girish C et al. Evaluation of Antiulcer Activity of Coccinia grandis Leaves. Research Journal of Pharmacology and Pharmacodynamics. 2011; 3:2011.

26. Gunjan Manish, Gautam K Jana, Jha AK, Umashankar Mishra. Pharmacognostic and Antihyperglycemic study on Coccinia Indica. International Journal of Phytomedicine. 2010; 2:36-40.

27. Gupta SS. Pituitary diabetes. III. Effect of indigenous antidiabetic drugs against the acute hyperglycemic response of anterior pituitary extract in glucose-fed albino rats Indian Journal of Medical Research. 1963; 51(4):716-724.

28. Jaiboon Vareerat, Boonyanuphap Jaruntorn, Sajee Suwansri, Puntarika Ratanatraiwong, Chanida Hansawasdi. Alpha amylase inhibition and roasting time of local vegetables and herbs $\backslash$ prepared for diabetes risk reducing chili paste. Asian Journal of Food and AgroIndustry. 2011; 14(2):03-113.

29. Jayaweera DM. Medicinal Plants (Indigenous and Exotic) used in Ceylon. Part 2. A Publication of the Natural Sciences Council of Srilanka, Colombo, 1980.

30. Khatun S, Pervin F, Karim MR, Ashraduzzaman M, Rosma A. Phytochemical screening and antimicrobial activity of Coccinia cordifolia L. Plant. Pakistan Journal of Pharm. Sci. 2012; 25:757-761.

31. Kritikar K, Basu BD. Indian Medicinal Plants. Bishen Singh Mahendra Pal singh, Dehra Dun (Repr. Ed.). 1975; 2:1006-1115.

32. Kumar GP, Sudheesh S, Ushakumari B, Valsa AK, Vijayakumar S, Sandhya C et al. A comparative study on the hypolipidemic activity of eleven different pectins. Journal of Food Science and Technology. 1997; 34(2):103-107.

33. Kusamran WR, Anong Tepsuwan, Piengchai Kupradinum. Antimutagenic and anticarcinogenic Potential of some Thai vegetables; Mutatation Research., 1998; 402(1,2):247-258.

34. Linney G. Coccinia grandis (L.) Voight: A new cucurbitaceous weed in Hawai, Hawaii. Bot. Soc. Newsletter. 1986; 25(5):3-5.

35. Mallick Chhanda, Chatterjee Kausik, Mehuli Guha Biswas, Debidas Ghosh. The antihyperglycemic effect of the separate and composite extract of root of Musa paradisiaca and leaf of Coccinia indica in streptozotocin 
induced diabetic male albino rats. Afr. J Trad. CAM. 2007; 4(3):362-371.

36. Manjula S, Ragavan B. Hypoglycemic and Hypolipidemic effect of Coccinia indica Wight \&Arn in alloxan induced diabetic rats. 2007; 27(2):34-7.

37. Manoharan Preeth, John Shobana, Golla Upendarrao, Dr. Thangathirupathi A. Antiulcer effect of coccinia grandis on pylorus grandis on pylorus ligated albino rats. International Journal of Pharma Research and Development. 2010; 2:1-9.

38. Maurice Navodita, Kumar Ashwani. Oviposition of Epilachna Vigintioctopunctata Fabricius on a wild weed. Coccinia grandis Linnaeus (Cucurbitales: Cucurbitaceae. Journal of Agricultural Extension and Rural Development. 2012; 4:41-45.

39. Moideen K, Haja Sherief S, Sengottuvelu S, Sivakumar T. Hepatoprotective and Antioxidant activity of coccinia grandis root extract against paracetamol induced hepatic oxidative stress in Wistar albino rats. International journal of research in Ayurveda and pharmacy. 2011; 2(3):858-863.

40. Molluscicidal properties of Polyscias fruticosa (L) harms. Ancient Science of Life. 1998; 17(4):313-319.

41. Mujumder Papiya Mitra, Sasmal D, Nimbi R Arivudai. Antiulcerogenic and antioxidant effect of Coccinia grandis leaves on aspirin induced gastric ulcer in rat. Natural product radians. 2008; 7(1):15-18.

42. Mukherjee K, Ghosh NC, Datta T. Coccinia indica as a potential hypoglycemic agent, Indian Journal of Experiment Biology. 1972; 5(10):347-349.

43. Nadkarni KM. Indian Materia Medica with Ayurvedic, Unani Products and Home Remedies. Popular Prakasham, Bombay, 1976, 1.

44. Nahar N, Mosihuzzaman M, Khan MD Shahinul H. Determination of free sugars in plant materials having antidiabetic activity. Dhaka Univ. J Sci. 1998; 46(1):167170.

45. Nanasombat S, Teckchuen N. Antimicrobial, antioxidant and anticancer activities of Thai local vegetables. Journal of Medicinal Plants Research. 2009; 3950:443-449.

46. Nath P. Cucurbitaceous vegetable in north India, university of Udaipur, college of Agriculture Jobner, Ext. Bull. 1966; 7:64.

47. Pattanayak Shakti Prasad, Priyashree Sunita. In vivo antitussive activity of Coccinia grandis against irritant aerosol and sulfur dioxide-induced cough model in rodents. Bangladesh Journal of Pharmacology. 2009; 4:84-87.

48. Pekamwar SS, Kalyankar TM, Kokate SS. Pharmacological activities of Coccinia grandis: review. Journal of Applied Pharmaceutical Science. 2013; 3(5):114-119.

49. Pekamwar SS, Kalyankar TM, Kokate SS. (Pharmacological Activities of Coccinia Grandis: Review). Journal of Applied Pharmaceutical Science. 2013; 3(5):114-119.

50. Perry LM. Medicinal Plants of East and South East Asia, Attributed properties and Uses, MIT Press, London, 1980.

51. Presanna Kumar G, Sudheeshi S, Vijayalakshmi NR. Hypoglycemic effect of Coccinia indica. Mechanism of Action, Planta Medica. 1997; 59(4):330-332.

52. Rahumann AA. Venkatesan larvicidal efficacy of five plant leaf extract against mosquito specious. journal of paracitol research. 2008; 103:133-139.
53. Saklani Akanksha, Parcha Versha, Dhulia Island, Deepak Kumar. Combined effect of Coccinia indica (Wight and Ann) and Salvadora Oleoids (decne) on blood glucose level and other risk factorassociated with type 2 diabetes mellitus in alloxan induced diabetic rats. International Journal of Pharmacy and Pharmaceutical Sciences. 2012; 4:78-84.

54. Samanta Amalesh, Bhattacharya Bolay, Ghosh Soma, Gouranga Das. In vivo antimalarial activity of the plant coccinia grandis. International journal of pharmaceutical research and development. 2011; 3(4):73-79.

55. Sastri BN. The Wealth of India, A Dictionary of Raw Material and Industrial Products, Publication and Information Directorate CSIR New Delhi. 1950; 2(8):257-285-293.

56. Sanskriti Gautam, Anju Meshram, Nidhi Srivastava. (A Brief Study on Phytochemical Compounds Present In Coccinia cordifolia for their Medicinal, Pharmacological and Industrial Applications). World Journal of Pharmacy and Pharmaceutical Sciences. 2014; 3(1):1995-2016.

57. Shibib BA, Khan LA, Rahman R. Hypoglycaemic activity of Coccinia indica and Momordica charantia in diabetic rats: depression of the hepatic gluconeogenic enzymes glucose-6- phosphatase and fructose1,6bisphosphatase and elevation of both liver and red-cell shunt enzyme glucose-6-phosphate dehydrogenase. Biochem. J. 1993; 292(1):267-270.

58. Singha Geetu et al. Antidyslipidemic activity of polyprenol from Coccinia grandis in high-fat diet-fed hamster model. Phytomedicine. 2007; 14:792-798.

59. Mishra Rakhi, Mishra Prem S, Ahmad Shamim. A Review on Herbal Treatment of Obesity. International Journal of pharmaceutical and chemical science. 2012; 1:523-525.

60. Sivaraj A et al., Antibacterial activity of Coccinia grandis leaf extract in selective bacterial strains. Journal of Applied Pharmaceutical Science. 2011; 1(07):120-123.

61. Amir Hossain SK, Sr. N Uddin, Md. Abu Salim, Razaul Haque. Phytochemical and Pharmacological screening of Coccinia grandis Linn). Journal of Scientific and Innovative Research. 2014; 3(1):65-71.

62. Starr Forest, Starr Kim, Lloyd Loope. Coccinia grandis Ivy gourd Cucurbitaceae. United States Geological Survey-Biological Resources Division Haleakala Field Station, Maui, Hawai'I January, 2003.

63. Sundaram Ravikumar, Samuel Jacob Inbaneson, Palavesam Suganthi. In vitro antiplasmodial activity of ethanolic extracts of South Indian Medicinal plants against Plasmodium falciparum. Asian Pacific Journal of Tropical Disease. 2012, 180-183.

64. Sunilson J Anbu Jeba et al. Hepatoprotective activity of Coccinia grandis against tetrachloride induced hepatic injury in rat. International Journal of pharmacology. 2009; 5:222-227.

65. Suresh Babu SKV, Rajan. A promising triploid of little guard. Journal of Tropical Agriculture. 2001; 39:162-163.

66. Syed Zeenat Shaheen, Gudikandula Krishna, Singara Charya MA. (Antifungal Activity of Coccinia Indica Extracts against Fungal Pathogens). International Journal of Pharmaceutical Science Invention Ver. 2018; 7(4):0610.

67. Tamilselvan $\mathrm{N}$ et al. Pharmacognosy of Coccinia grandis: a review. Asian Pacific Journal of Tropical Biomedicine. 2011; 1(1):S299-S302. 
68. Vadivu R et al. Evaluation of Hepatoprotective Activity of the Fruits of Coccinia grandis Linn. International Journal of Health Research. 2008; 1(3):163-168.

69. Vinothkumar P, Sivaraj A, Elumalai EK, Sentil Kumar B. Carbon tetrachloride induced Hepatotoxicity in ratsprotective role of aqueous leaf extracts of coccinia. International Journal of Pharm Tech Research. 2009; 1:1612-1615.

70. Wealth of India. A dictionary of Indian raw materials and India products. Raw Material, New Delhi. 1992; 4:312. 